\title{
Are Sustainable Firms More Profitable? Evidence From Egypt
}

\author{
Nisreen Mohammed Almaleeh \\ Accounting department, Faculty of Commerce \\ Menofia University, Egypt \\ E-mail: nesreen.mohamed@commerce.menofia.edu.eg
}

Received: December 2, 2018 Accepted: December 29, 2018 Published: January 21, 2019

doi:10.5296/ijafr.v9i1.13984

URL: https://doi.org/10.5296/ijafr.v9i1.13984

\begin{abstract}
The purpose of this study is to investigate the association between adopting sustainability practices by Egyptian companies and their level of profitability. Three hypotheses were tested, the first concerned whether sustainable firms achieve higher levels of market value of equity than non-sustainable firms, the second involved whether sustainable firms have higher levels of return on equity compared to non-sustainable ones, and the last was about the amount of cash dividends paid by sustainable firms to their stockholders as opposed to non-sustainable ones. The population of 221 Egyptian companies listed in the Egyptian stock market in the year 2015 was used to test these hypotheses. The results demonstrate that sustainability practices are associated with higher level of both market value of equity and return on equity. Furthermore, cash dividends paid to stockholders are proven to be higher for sustainable firms.
\end{abstract}

Keywords: Egyptian stock market, Financial performance, Profitability, Sustainability

\section{Introduction}

Recent evidence suggests that traditional financial statements do not incorporate all the factors that would have an impact on the business's long term ability to create value. A great portion of this "value gab" can be linked to the management of environmental, social, and human aspects of business. Therefore, corporate reporting must include these aspects in addition to traditional financial statements to include the measurement and reporting of sustainability information leading to the enhancement of decision maker's understanding of potential risks and opportunities. 
As a result of the above, corporate sustainability captured the attention of a lot of researchers in the last two decades (Schaltegger et al., 2013). It is defined as the integration of financial benefit, environmental protection, and social responsibility into business operations and management (Lo, 2010). According to the Global Reporting Initiative (GRI, 2011) the social dimension of sustainability is related to the effect that the business may have on social systems in which it operates. While the economic dimension refers to the effects that the business may have on the economic conditions of its stakeholders and on local, national, and global economic systems.

Considering that accounting is an important measurement system of business activities, there is a growing amount of pressure imposed on professional accountants to better integrate sustainability into businesses' decision making process to direct their decisions towards sustainable development. The role of accounting is becoming more crucial nowadays because of the inadequacy of natural resources and the social problems that are becoming more enormous for present and future generations (Caliskan, 2014). As the accounting profession is considered as a reflection of the economic, managerial, and societal developments that occur in its surrounding environment, the interest in sustainability accounting is growing internationally .More accountants are becoming aware of the triple bottom line (TBL) sustainability performance measurement model (Bremser, 2014), the three dimensions of the TBL model are interrelated and are referred to as the "three Ps" (profit, people, and planet).

Focusing on Egypt as an emerging economy, sustainability performance measurement is increasingly recognized as a serious concern. A considerable number of Egyptian companies disclose their environmental and social activities. In addition to that, The Egyptian Exchange (EGX) launched its S\&P EGX ESG index in March 2010; the first \& only ESG index in the Middle East and North Africa Region designed to track the performance of companies listed on EGX that demonstrate leadership in environmental, social and corporate governance (ESG) issues. This Index aims to raise the profile of those companies that perform well in the areas of environmental, social, and corporate governance responsibility when compared to their market peers (EGX, 2016).

This has drawn my attention to the question of this study; do sustainable firms achieve higher levels of financial performance as opposed to non-sustainable ones? More specifically, do they achieve higher levels of profitability?

\section{Literature Review}

The increased focus towards responsible and sustainable development has attracted the attention of both regulators and researchers, recent evidence suggests that there is a dominant movement by regulations from voluntary adoption of sustainability practices towards a more mandatory and strict application (Bodhanwala \& Bodhanwala,2018). On the side of researchers, a considerable amount of attempts have been made globally to analyze the association between sustainability and multiple variables including firm's performance.

Recently, researchers have shown increased interest in exploring the benefits that companies may obtain from being sustainability leaders; such as improved brand reputation, improved employee productivity, increased operating efficiency, gaining competitive advantage, and improved relations with regulators, society, and other stakeholders (Yu \& Zhao, 2015; Asif et 
al.,2011; Herzig \& Schaltegger,2011). In the same vein, (Reverte, 2009) found that corporate interest in sustainability reporting could result in a better competitive advantage, an increased level of public relations, and recognition of the efforts undertaken by the firm.

Referring to the triple bottom line (TBL) sustainability performance measurement model, sustainability practices include environmental, social, and economic aspects. As for the environmental aspect, the adoption of eco-efficient business strategies and environmental disclosures are found to be positively related to firm value (Henao, 2018; Moneva \& Cuellar, 2009; Sinkin et al., 2008; Lo \& Sheu, 2007). Although these studies are mainly about environmental performance and reporting, they represent a scientific background for sustainability accounting. However, environmental performance is just one of the various aspects of sustainability.

The second aspect of sustainability is social performance.Berthelot et. al. (2012) found that sustainable development reports are often called "corporate social responsibility reports" and have been gradually replacing environmental reports issued by companies. The informative content of corporate social responsibility reports CSR was found to be valued by stock participants and showed improvements on stock prices (Jizi at al., 2016). Besides, long term investors consider corporate social and environmental behavior as material to investment decisions due to the competitive advantage CSR might give to the firm. (Aguilera et al., 2006)

Investigating other types of benefits that businesses may achieve by being committed to suitability practices, a number of researchers have reported that firms that practice remarkable sustainable development strategies report higher profitability. Bodhanwala\& Bodhanwala (2018) found that firms that engage in sustainability practices record higher values of return on invested capital, return on equity, return on assets, and earnings per share as compared to firms that show less interest in sustainability measures. Similarly, Semenova et al. (2010) concluded that companies with higher environmental and social performance tend to achieve higher returns, while companies with the lowest scores achieve lower ones. Additionally, in efficient markets, all disclosed information whether financial or nonfinancial, leads to reducing the degree of information asymmetry (Cho et al. 2013) which -in turnenhances the firm's ability to access finance in capital markets, reduces its cost of capital and returns volatility (Kothari et al., 2009; El Ghoul et al.,2011; Cheng et al.,2013).

Moreover, the integration of environmental and social responsibility into corporate strategies and practices reduce firm risk (Zahid\& Ghazali, 2017; Jo \& Na, 2012). Sustainability is becoming a vital instrument for minimizing conflicts among various stakeholders, resulting in less risky corporate behavior and stable growth (Godfrey et al., 2009). Sustainability in the organization is a unique process of how business operations are designed and conducted in such a way that lead to higher organizational performance and better decision making, which -in turn- leads to a better implementation of risk management framework. All of this will improve the overall economic value of the organization (Shad et. al., 2019).

It was also found that sustainable firms are partially rewarded for their sustainable development strategies. A number of researchers demonstrated that in terms of profitability, sustainable firms generally perform better that other firms, implying that the firm's 
sustainable strategy helps in generating profit given limited input resources (Xiao et. al., 2018; Ameer\& Othman, 2012; Lo, 2010, Artiach et. al., 2010).

Overall, there seems to be some evidence that indicates a positive effect on a firm's performance - on both financial and nonfinancial levels- if it chooses to engage in sustainability activities. However, Yu \& Zhao (2015) found that the valuation premium for companies that are environmentally and socially responsible and well governed, is higher in countries with stronger investor protection. Furthermore, the premium is more pronounced for firms operating in higher financial transparency environments.

Looking at the other side, numerous researches have emerged offering contradictory findings about the relationship between corporate sustainability and firm performance measures. Some studies report inconclusive and mixed results which can be attributed to the period of the study, the region of application, or the methodology applied by researchers. A number of researches pointed out the firm's social and environmental practices are likely to impose an additional cost that may have a negative effect on its profitability (Lopez, 2007; Wanger et al., 2002; Jaggi \& Freedman, 1992). Another research attempts argued that there might not be a significant relation between corporate sustainability and its profitability levels. They found that firms that do not make efforts with regard to their social and environmental performance may have a better chance to offer their products and services at competitive prices. (Aras et. al., 2010; Garcia-Castro et. al., 2010;Surroca et. al., 2010;Abagail \&Siegel, 2000; Mill, 2006; Murray et al., 2006)

This study fits into the above mentioned background and tries to offer a key to understanding the possible relationship between a corporate being sustainable and its level of profitability in emerging markets, using the Egyptian market as an example. It is expected that this study offer several contributions to the scientific debate. First, it enriches the existing literature on the potential improved performance of sustainable firms. Second, it contributes to filling the gab of existing literature about sustainability performance in emerging capital markets. In addition, so far there has been -to the best of my knowledge- no empirical studies that test the effect of sustainability performance on the firm's profitability in Egypt, and that is what this study is trying to do.

\section{Research Design and Data Collection}

\subsection{Hypotheses Development}

Traditionally, it has been argued that there is a direct effect of sustainability practices undertaken by firms and their market value (Greeves \& Ladipo, 2004; Schadewitz \& Niskala, 2010). According to (Cardamone et al,2011) sustainability reports publication can also have an indirect impact on the firm's stock price, because they are received by investors as a source of future information about the nature, composition, and trends of the traditional accounting measures.

According to the above considerations, and as this study is trying to explore the relationship between the firm being sustainable, and its potential to achieve higher levels of profitability, it is going to test the following hypothesis:

H1: Sustainable firms have higher market value of equity. 


\section{MIN Macrothink}

International Journal of Accounting and Financial Reporting

ISSN 2162-3082

2019, Vol. 9, No. 1

Recent evidence suggests that a firm's environmental or social practices interact with stakeholders' preferences, and finally induce financial gains to firms (Bodhanwala\& Bodhanwala, 2018; Lo, 2010). Many empirical studies have uncovered a positive relationship between corporate sustainability practices and its financial benefits (King \& Lenox, 2002; Schnietz \& Epstein, 2005; Lo \& Sheu, 2007). In the light of these findings, this study will test the following hypothesis:

$\mathrm{H} 2$ : Sustainable firms have a higher level of return on equity.

One of the most important and controversial issues in corporate finance is answering the question of whether dividend changes gives information about future earnings and profitability. In this context, various studies have found that dividend changes are positively correlated with future profitability (Nassim \& Ziv, 2001; John \&Williams, 1985; Miller \& Rock, 1985).

Taking into account the above, considering that this study aims to answer the question of whether corporate sustainability practices have an impact on corporate profitability, it will test the following research hypothesis:

H3: Sustainable firms pay more cash dividends to stockholders.

\subsection{Data}

This study examines whether corporate sustainability practices has an impact on corporate profitability or not. This is done using data of the 221 Egyptian corporations listed in the Egyptian stock market in the year 2015; these firms were classified into two groups according to the following criteria:

Group (1): are firms that are included in the S\&P/EGX ESG Index that includes Egyptian companies with the highest score in terms of environmental, social and corporate governance responsibility. This index includes 30 stocks from the pool of 100 Egyptian companies screened annually, and uses an innovative score-weighting scheme. (EGX, 2016)

Table 1. S\&P/EGX ESG Index constituents and their weights

\begin{tabular}{lll}
\hline ISIN Code & COMPANY & Weight \\
\hline EGS60121C018 & Commercial International Bank (Egypt) S.A.E. & $4.24 \%$ \\
\hline EGS69101C011 & Egyptian Financial Group-Hermes Holding Company & $3.68 \%$ \\
\hline EGS74081C018 & Global Telecom Holding & $3.66 \%$ \\
\hline EGS42051C010 & Egyptian Transport (EGYTRANS) & $3.63 \%$ \\
\hline EGS65851C015 & Six of October Development \& Investment (SODIC) & $3.56 \%$ \\
\hline EGS95001C011 & Orascom Construction Limited & $3.54 \%$ \\
\hline EGS694A1C018 & Porto Group Holding & $3.51 \%$ \\
\hline EGS73541C012 & Citadel Capital Corp & $3.47 \%$ \\
\hline
\end{tabular}


EGS3C0O1C016 Arabian Cement Company $\quad 3.46 \%$

\begin{tabular}{|c|c|c|}
\hline EGS69082C013 & Egyptian Kuwaiti Holding & $3.42 \%$ \\
\hline EGS675S1C011 & Amer Group Holding & $3.38 \%$ \\
\hline EGS673Y1C015 & Emaar Misr for Development & $3.38 \%$ \\
\hline EGS690C1C010 & Raya Holding For Technology And Communications & $3.33 \%$ \\
\hline EGS380S1C017 & Sidi Kerir Petrochemicals & $3.30 \%$ \\
\hline EGS655L1C012 & Palm Hills Development Company & $3.30 \%$ \\
\hline EGS3C071C015 & El Ezz Ceramics \& Porcelain & $3.25 \%$ \\
\hline EGS65571C019 & Medinet Nasr Housing & $3.25 \%$ \\
\hline EGS3G0Z1C014 & El sewedy Electric company & $3.23 \%$ \\
\hline EGS3C181C012 & Suez Cement & $3.22 \%$ \\
\hline EGS380P1C010 & Alexandria Mineral Oils Company & $3.22 \%$ \\
\hline EGS69182C011 & Naeem Holding & $3.21 \%$ \\
\hline EGS3C251C013 & Ezz Steel & $3.20 \%$ \\
\hline EGS42111C012 & Alexandria Containers and Goods & $3.18 \%$ \\
\hline EGS673T1C012 & GB Auto & $3.12 \%$ \\
\hline EGS691S1C011 & Talaat Moustafa Group Holding & $3.09 \%$ \\
\hline EGS305I1C011 & Edita Food Industries S.A.E & $3.07 \%$ \\
\hline EGS33041C012 & Oriental Weavers & $3.07 \%$ \\
\hline EGS48031C016 & Telecom Egypt & $3.06 \%$ \\
\hline EGS38311C014 & Paint \& Chemicals Industries (Pachin) & $3.06 \%$ \\
\hline EGS67221C019 & Arab Moltaka Investments & $2.94 \%$ \\
\hline
\end{tabular}

Group (2): contains the remaining 191 firm.

For each company in both groups -after excluding the companies with missing data- 4 types of data is collected .First, a dummy variable is assigned to the company to show whether it is sustainable or not: 1 if sustainable (included in the EGX ESG ) \& 0 if not. Secondly, market value of equity will be calculated as the company's annual average market price of shares multiplied by its number of outstanding shares. Thirdly, return on equity is calculated as net 


\section{Macrothink}

International Journal of Accounting and Financial Reporting

ISSN 2162-3082 2019, Vol. 9, No. 1

income divided by stockholders' equity. Lastly, cash dividends paid to shareholders will be obtained from the company' financial statements.

\section{Empirical Analysis}

Because this study uses the data of the entire population of the Egyptian corporations listed in the Egyptian stock market in the year 2015, it doesn't depend on statistical tests to answer its question. Rather, it tries to answer the research question through comparing sustainable and non-sustainable firms in terms of their average market value of equity, return on equity, and cash dividends paid to stockholders. These three variables were collected/calculated for the entire population of 221 companies, after companies with missing data were excluded; descriptive data were generated for the three variables as the following table shows:

Table 2. Descriptive statistics of research variables

\begin{tabular}{lllll}
\hline Variable & Minimum & Maximum & Mean & Std. deviation \\
\hline Market value of equity & 17,711 & $49,668,707$ & $2,054,374$ & $5,410,333$ \\
\hline Return on equity & 0 & 55.7 & 11.57 & 12.48 \\
\hline Cash dividends & 0 & $1,563,646$ & 77,403 & 200,521 \\
\hline
\end{tabular}

As for the first hypothesis and after dividing the population to sustainable and non-sustainable firms, the average of the market value of equity is calculated for each group, the result is shown in the following figure:

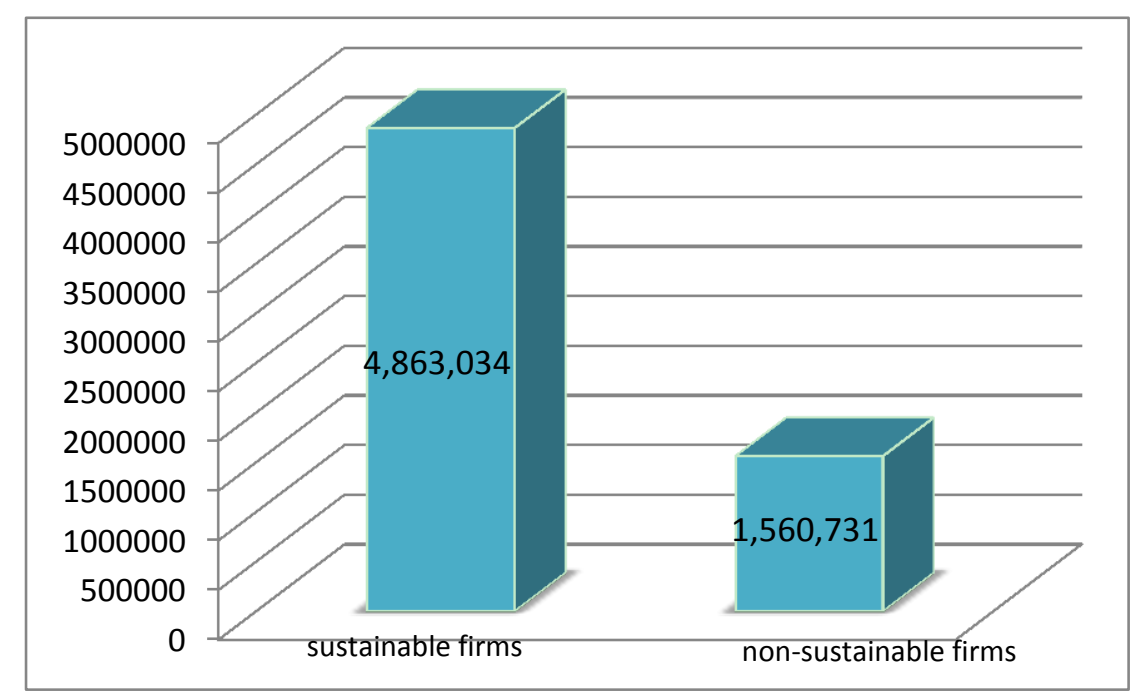

Figure 1. Market value of equity in sustainable versus non-sustainable firms

This figure shows that sustainable firms have a much higher market value of equity as opposed to non-sustainable ones. The average market value of equity for sustainable firms is 4,863,034 L.E. -which is more than twice the population average $(2,054,374)$ - while for non-sustainable firms it is 1,560,731 L.E. only. So, the first hypothesis is accepted, sustainable firms do have higher market value of equity. 


\section{Mll Macrothink}

International Journal of Accounting and Financial Reporting

ISSN 2162-3082 2019, Vol. 9, No. 1

If we now turn to the second hypothesis, the population was divided to sustainable and non-sustainable firms, and then the average return on equity was calculated for each group, the result is shown in the following figure:

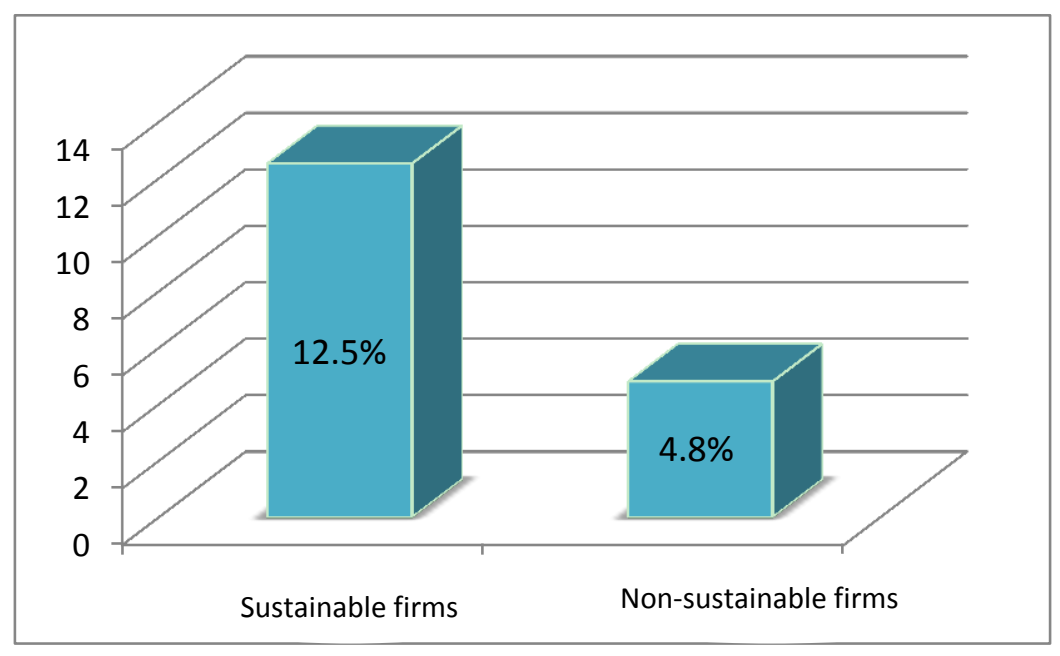

Figure 2. Return on equity in sustainable versus non-sustainable firms

As this figure shows, sustainable firms have a much higher return on equity percentage in comparison with non-sustainable ones. The average return on equity for sustainable firms is $12.5 \%$-which is slightly above the population average $(11.57 \%)$ - while for non-sustainable firms it is $4.8 \%$ only. Considering that, the second hypothesis is also accepted, sustainable firms do have higher return on equity.

In the final part of this study, the third hypothesis was tested by collecting the data about cash dividends paid to stockholders for both sustainable and non-sustainable firms, and then the average cash dividends was calculated for each group, the result is shown in the following figure:

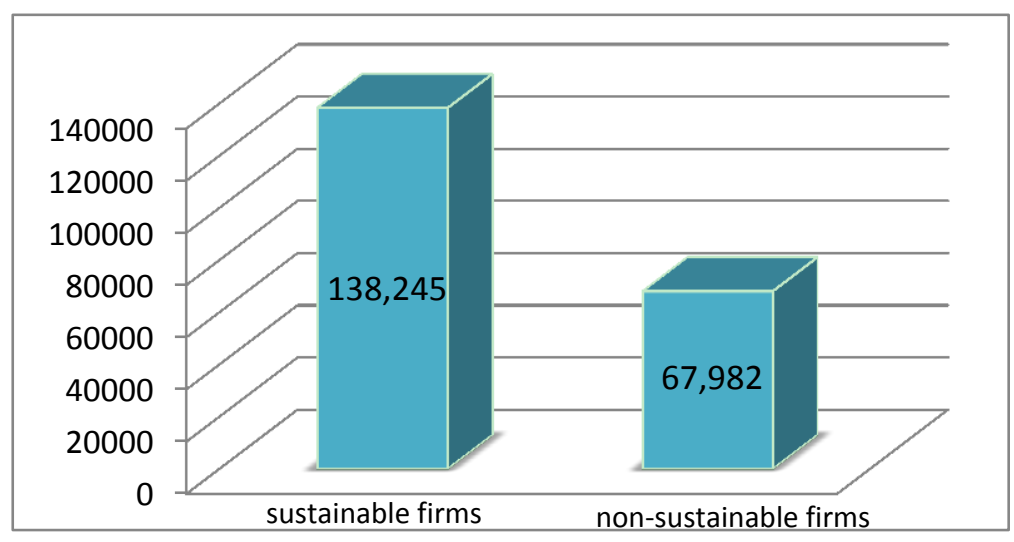

Figure 3. Cash dividends paid to stockholders in sustainable versus non-sustainable firms

Looking at this figure, sustainable firms paid a much higher amount of cash dividends than the non-sustainable firms did. The average amount of cash dividends paid by sustainable firms is 138,245 L.E. -which is significantly above the population average (77,403 L.E.) while for non-sustainable firms it is only 67,982 L.E. According to this result, the third 
hypothesis is accepted; sustainable firms do pay larger amounts of cash dividends to stockholders.

Taken together, these results suggest that there is an association between the firm being engaged in sustainability practices and its level of profitability.

\section{Discussion and Conclusion}

The purpose of the current study was to investigate the association between adopting sustainability practices by Egyptian companies and their level of profitability. I tested three hypotheses, the first concerned whether sustainable firms achieve higher levels of market value of equity than non-sustainable firms, the second involved whether sustainable firms have higher levels of return on equity compared to non-sustainable ones, and the last was about the amount of cash dividends paid by sustainable firms to their stockholders as opposed to non-sustainable ones.

To answer these questions, I used the population of Egyptian companies listed in the Egyptian stock market in the year 2015. In my models, being sustainable was accounted for by a dummy variable equal to 1 if the company is included in the EGX/ESG index or 0 otherwise, market value of equity and return on equity were calculated for all the tested companies, and data about cash dividends was obtained from companies' financial statements. Egyptian companies that were tested were 221 companies divided into two groups: 30 sustainable firms and 191 non-sustainable ones.

The descriptive statistics showed that market value of equity, return on equity, and cash dividends are higher in sustainable firms, these results demonstrate that -all other factors being equal- sustainability practices are associated with higher level of both market value of equity and return on equity. Furthermore, cash dividends paid to stockholders are proven to be higher for sustainable firms.

These findings are consistent with those of other studies that concluded that engaging in sustainability activities contributes to the firm's current and potential level of profitability. They are also consistent with those of other studies that suggested that sustainability practices lead to higher levels of returns and improved performance in terms of profitability ((Bodhanwala\& Bodhanwala, 2018;Semenova et al, 2010; Lo, 2010)

However, these results differ from some other studies (Aras et. al., 2010; Garcia-Castro et. al., 2010; Surroca et. al., 2010; Murray et al., 2006; Mill, 2006; Wanger et al., 2002) which didn't define a clear association between sustainability practices and profitability indicators. It is difficult to explain this contradiction, but it might be related to the high level of costs associated with sustainability practices which may have a negative impact on the firm's level of profitability.

These results are unique to the Egyptian market in which this study was implemented. It is an emerging and less well established market than those of developed countries. Therefore, these results are not applicable to all stock markets, and more research on this topic needs to be 
undertaken before the association between sustainability practices and profitability is more clearly understood.

\section{References}

Abagail, M., \& Siegel, D. (2000). Corporate social responsibility and financial performance: Correlation or misspecification. Strategic Management Journal, 21(5), 603-609.

Aguilera, R. V., Williams, C. A., Conley, J. M., \& Rupp, D. E. (2006). Corporate governance and social responsibility: A comparative analysis of the UK and the US. Corporate Governance: An International Review, 14(3), 147-158.

Ameer, R., \& Othman, R. (2012). Sustainability practices and corporate financial performance: A study based on the top global corporations. Journal of Business Ethics, 108(1), 61-79.

Aras, G., Aybars, A., \& Kutlu, O. (2010). Managing corporate performance: Investigating the relationship between corporate social responsibility and financial performance in emerging markets. International Journal of productivity and Performance management, 59(3), 229-254.

Artiach, T., Lee, D., Nelson, D., \& Walker, J. (2010). The determinants of corporate sustainability performance. Accounting \& Finance, 50(1), 31-51.

Asif, M., Searcy, C., Zutshi, A., \& Ahmad, N. (2011). An integrated management systems approach to corporate sustainability. European Business Review, 23(4), 353-367.

Berthelot, S., Coulmont, M., \& Serret, V. (2012). Do investors value sustainability reports? A Canadian study. Corporate Social Responsibility and Environmental Management, 19(6), 355-363.

Bodhanwala, S., \& Bodhanwala, R. (2018). Does corporate sustainability impact firm profitability? Evidence from India. Management Decision, 56(8).

Bremser, W. G. (2014, March). A growing interest in sustainability: paving the way for the next generation of CPAs. The CPA Journal, 15-17.

Caliskan, A. O. (2014). How accounting and accountants may contribute in sustainability?. Social Responsibility Journal, 10(2), 246-267.

Cardamone, P., Carnevale, C., \& Giunta, F. (2012). The value relevance of social reporting: evidence from listed Italian companies. Journal of Applied Accounting Research, 13(3), 255-269.

Cheng, B., Ioannou, I., \& Serafeim, G. (2014). Corporate social responsibility and access to finance. Strategic Management Journal, 35(1), 1-23.

Cho, S. Y., Lee, C., \& Pfeiffer, R. J. (2013). Corporate social responsibility performance and information asymmetry. Journal of Accounting and Public Policy, 32(1), 71-83. 
El Ghoul, S., Guedhami, O., Kwok, C. C., \& Mishra, D. R. (2011). Does corporate social responsibility affect the cost of capital?. Journal of Banking \& Finance, 35(9), 2388-2406.

Garcia-Castro, R., Ariño, M. A., \& Canela, M. A. (2010). Does social performance really lead to financial performance? Accounting for endogeneity. Journal of Business Ethics, 92(1), 107-126.

Global Reporting Initiative. (2011). Sustainability Reporting Guidelines. GRI, Amesterdam, The Netherlands.

Godfrey, P. C., Merrill, C. B., \& Hansen, J. M. (2009). The relationship between corporate social responsibility and shareholder value: An empirical test of the risk management hypothesis. Strategic Management Journal, 30(4), 425-445.

Greeves, L., \& Lapido, D. (2004). Added Values? Measuring the 'Value Relevance' of Sustainability Reporting. Imagination (GIC) and Lintstock: London.

Henao, R., Sarache, W., \& Gómez, I. (2018). Lean Manufacturing and Sustainable Performance: trends and future challenges. Journal of Cleaner Production, 208(20), 99-116.

Herzig, C., \& Schaltegger, S. (2011). Corporate sustainability reporting: an overview. Sustainability Accounting and Reporting, pp.301-324. Springer Netherlands.

Jaggi, B., \& Freedman, M. (1992). An examination of the impact of pollution performance on economic and market performance: pulp and paper firms. Journal of Business Finance \& Accounting, 19(5), 697-713.

Jizi, M., Nehme, R., \& Salama, A. (2016). Do social responsibility disclosures show improvements on stock price?. The Journal of Developing Areas, 50(2), 77-95.

Jo, H., \& Na, H. (2012). Does CSR reduce firm risk? Evidence from controversial industry sectors. Journal of Business Ethics, 110(4), 441-456.

John, K., \& Williams, J. (1985). Dividends, dilution, and taxes: A signaling equilibrium. The Journal of Finance, 40(4), 1053-1070.

King, A., \& Lenox, M. (2002). Exploring the locus of profitable pollution reduction. Management Science, 48(2), 289-299.

Kothari, S. P., Li, X., \& Short, J. E. (2009). The effect of disclosures by management, analysts, and business press on cost of capital, return volatility, and analyst forecasts: A study using content analysis. The Accounting Review, 84(5), 1639-1670.

Lo, S. F. (2010). Performance evaluation for sustainable business: a profitability and marketability framework. Corporate Social Responsibility and Environmental Management, 17(6), 311-319.

Lo, S. F., \& Sheu, H. J. (2007). Is corporate sustainability a value-increasing strategy for business?. Corporate Governance: An International Review, 15(2), 345-358. 


\section{$\triangle 1$ Macrothink}

International Journal of Accounting and Financial Reporting

ISSN 2162-3082

López, M. V., Garcia, A., \& Rodriguez, L. (2007). Sustainable development and corporate performance: A study based on the Dow Jones sustainability index. Journal of Business Ethics, 75(3), 285-300.

Mill, G. A. (2006). The financial performance of a socially responsible investment over time and a possible link with corporate social responsibility. Journal of Business Ethics, 63(2), 131-148.

Miller, M. H., \& Rock, K. (1985). Dividend policy under asymmetric information. The Journal of finance, 40(4), 1031-1051.

Moneva, J. M., \& Cuellar, B. (2009). The value relevance of financial and non-financial environmental reporting. Environmental and Resource Economics, 44(3), 441-456.

Murray, A., Sinclair, D., Power, D., \& Gray, R. (2006). Do financial markets care about social and environmental disclosure? Further evidence and exploration from the UK. Accounting, Auditing \& Accountability Journal, 19(2), 228-255.

Nissim, D., \& Ziv, A. (2001). Dividend changes and future profitability. The Journal of Finance, 56(6), 2111-2133.

Reverte, C. (2009). Determinants of corporate social responsibility disclosure ratings by Spanish listed firms. Journal of Business Ethics, 88(2), 351-366

S\&P Dow Jones Indices. (2016, November). S\&P Jones Indices: S\&P/EGX ESG Index methodology.

Schadewitz, H., \& Niskala, M. (2010). Communication via responsibility reporting and its effect on firm value in Finland. Corporate Social Responsibility and Environmental Management, 17(2), 96-106.

Schaltegger, S., Gibassier, D., \& Zvezdov, D. (2013). Is environmental management accountinga discipline? A bibliometric literature review. Meditari Accountancy Research, 21(1), 4-31.

Schnietz, K. E., \& Epstein, M. J. (2005). Exploring the financial value of a reputation for corporate social responsibility during a crisis. Corporate Reputation Review, 7(4), 327-345.

Semenova, N., Hassel, L. G., \& Nilsson, H. (2010). The Value Relevance of Environmental and Social Performance: Evidence from Swedish SIX 300 Companies. Liiketaloudellinen Aikakauskirja, No.3.

Shad, M. K., Lai, F. W., Fatt, C. L., Klemeš, J. J., \& Bokhari, A. (2019). Integrating sustainability reporting into enterprise risk management and its relationship with business performance: A conceptual framework. Journal of Cleaner Production, 208, 415-425.

Sinkin, C., Wright, C. J., \& Burnett, R. D. (2008). Layoff announcements and stockholder wealth. Journal of Accounting and Public Policy, 27(2), 167-176. 


\section{Mll Macrothink}

International Journal of Accounting and Financial Reporting ISSN 2162-3082

Surroca, J., Tribó, J. A., \& Waddock, S. (2010). Corporate responsibility and financial performance: The role of intangible resources. Strategic Management Journal, 31(5), 463-490.

Wagner, M., Van Phu, N., Azomahou, T., \& Wehrmeyer, W. (2002). The relationship between the environmental and economic performance of firms: an empirical analysis of the European paper industry. Corporate Social Responsibility and Environmental Management, 9(3), 133-146.

Xiao, C., Wang, Q., van der Vaart, T., \& van Donk, D. P. (2018). When does corporate sustainability performance pay off? The impact of country-level sustainability performance. Ecological Economics, 146, 325-333.

Yu, M., \& Zhao, R. (2015). Sustainability and firm valuation: an international investigation. International Journal of Accounting and Information Management, 23(3), 289-307.

Zahid, M., \& Ghazali, Z. (2017). Corporate Sustainability Practices and Firm's Financial Performance: The Driving Force of Integrated Management System. Global Business \& Management Research, 9.

\section{Copyright Disclaimer}

Copyright for this article is retained by the author(s), with first publication rights granted to the journal.

This is an open-access article distributed under the terms and conditions of the Creative Commons Attribution license (http://creativecommons.org/licenses/by/4.0/) 